\title{
DO DIGITAL TECHNOLOGIES HAVE THE POWER TO DISRUPT COMMERCIAL BANKING?
}

\section{Gordana Golubić *}

\begin{abstract}
The hypothesis guiding this paper is if digital technologies have the power to alter the commercial banks' set-up and the way they provide their services. This would suggest that the new types of (traditional) banking services and the new type of (traditional) banking service providers have emerged in the market. The paper describes the commercial banking services, the set-up commercial banks operate in and the changes occurring in the market triggered by financial technology (the FinTech firms). When researching the effects of financial technology, the paper focuses on the trends in the market and the efficiencies the new services are responsible for. The new service providers have shown that they are meeting the demands of the consumers/clients that banks have not, such as crowdfunding, or battling financial inclusion. The grand issue surrounding the FinTech sector is the lack of applicable regulatory environment. Challenges the regulators are faced with when designing the regulation applicable to the financial technology are the speed the services are evolving with and choosing the right moment to place regulation. The lack of adequate regulation leaves customers/clients unprotected. Nevertheless, the FinTech sector is growing rapidly. Indications in the market suggest the FinTech firms are leading the way the commercial banking sector will follow.
\end{abstract}

KEYWORDS: commercial banking, FinTech, financial inclusion, crowdfunding, RegTech, blockchain

Legal Trainee at Golubić \& Partners GP, Zagreb; gordana.golubic@golubic.net 


\section{INTRODUCTION}

In the recent decade, significant turmoil has occurred in financial markets. The financial sector has been facing various challenges, starting with the financial crises of 2007/2008, the emergence of digital technology such as various applications providing banking services and finally the popularization of cryptocurrencies such as bitcoin. This paper will explore if modern technology has the potential to disrupt the commercial banking sector. It will focus on how it is affecting commercial banks and the services they are providing.

More specifically, this paper will explore the use of digital infrastructure in global markets in order to identify what effect it may have on the commercial banking industry. The reason for that is the link between financial markets. A phenomenon that is taking place in one financial market, may often impact other markets. Consequently, the banking industry of one country may be moved by the trends in other countries. This is compounded by digital technology service providers increasingly providing their services to their customers online. This means that services being offered will, in most cases, be accessible to a number of clients, regardless of the country they ordinarily reside in. Therefore, the alterations that are occurring cannot be observed from only one market's perspective. That is why this paper does not focus on the changes occurring in a single market.

The literature used for the creation of this paper is: the books and papers of the prominent authors together with the reports of established international institutions and private business consultants. Well-known dictionaries have been used for specifying the definitions used in this paper. The research for this paper was conducted on the Internet. Therefore, various Internet sources were used in the preparation of this paper with the purpose of illustrating the occurrences and the developments in the market.

The topic of this paper is not the financial crisis 2007/2008 nor if the emergence and the popularity of digital technology providers is the after-effect of the financial crisis. This paper is observing the state of the market after the financial crisis and exploring its effect on the set-up of commercial banks and the services they are providing. The financial crisis in this paper is referred to as financial crisis 2007/2008. The term bank or banking in this paper is referred to as commercial or retail banking if not expressively stated otherwise. The effect of digital technology on investment banking or the investment banking services is not the topic of this paper.

In the second chapter, this paper provides a display of the transformative effects that the implementation of digital technology could have on an industry and compares this with examples from the communication industry. The third 
chapter proposes a definition of commercial banks and the services they provide. The fourth chapter outlines the technological solutions benefitting the clients that have been implemented so far in the banking sector. The fifth chapter will define FinTech firms and touch upon the challenges there are facing. It will also review the services FinTech is providing and compare them to the services commercial banks are providing. The sixth chapter of the paper will discuss the regulatory environment, the lack of a suitable regulatory framework, and the challenges the legislators are facing. This paper concludes with a discussion on the regulatory environment, the lack of suitable regulatory framework, the challenges that legislators are facing and the expectation of the market and whether digital technologies are disrupting commercial banking services.

\section{DIGITAL TECHNOLOGIES' ALTERING EFFECT ON THE ESTABLISHED MARKETS}

Digital technologies are deeply embedded in modern society, and it is assumed they will be influencing the banking sector, and the services banks are providing. Prior to the implementation of digital technology, it is challenging to forecast the effects it will have on the established infrastructures. Hence are the depth and the intensity of the penetration of digital technology into the financial system unconceivable. The influence and the transformative power digital technology may have on commercial banking sector cannot be fully foreseen. The effect the implementation of digital technologies may have on the industry can, however, be observed on the example of communications industry where the implementation of digital technology has made drastic alterations.

During the first and the second industrial revolution, the innovations in the communication sector have simplified communication (telegraph and telephone) and allowed more individuals access to media and the news (radio and TV). Although the impacts of the first and second revolution on communication were transformative, it cannot be compared with how markets and commerce have been revolutionized by digital technologies such as computer and Internet.

The Internet, social media and smartphones have changed the way people communicate and engage with each other as well as, more recently, financial services. The implementation of the digital technologies into the communications infrastructure has reduced the cost, increased the speed and the efficiency of the communication by which it has provided (previously) unthinkable methods of communication (such as video-chats). The use of digital infrastructure permits and also facilitates news and information to travel inexpensively 
and instantly from one part of the world to another. It allows every person with a smartphone and an appropriate social media account to be a reporter. As a result, the methods of communication and media are utterly transformed. Such an efficient transformation has rendered some old technologies and infrastructures such as fixed telephones and fixed lines as fallbacks and/or obsolete.

New(er) technologies and their implementation in the existing infrastructures may become relevant and achieve benefits provided that an adequate number of users accept them. For that reason, when assessing the impact of the innovative technologies on the society and industry, the adaption speed by which the users accept them must be taken into account. The telephone has had 50 million connections 30 years after its invention, the iPod has reached the same user number in 5 years, and Skype has reached 50 million users in only 2 years. ${ }^{1}$ The listed examples display that the adaption speed is increased for each new product (and service). As technological adoption increases so does the need for more ${ }^{2}$. Some of the reasons why is the adaption speed increasing are the globalization and the global consumers connected through social media and other platforms.

\section{COMMERCIAL BANKS AND THE SERVICES THEY ARE PROVIDING}

With the purpose of assessing the disrupting or altering effect of the digital technology on the services of commercial banks, this paper will firstly define a (commercial) bank and the services it traditionally provides. Black's Law Dictionary defines a bank as a financial establishment for the deposit, loan, exchange, or issue of money and for the transmission of funds. ${ }^{3}$ One of the first precise definitions of banks was in the US Bank Holding Companies Act which defined banks as institutions that accept demand deposits or deposits that the depositor may withdraw by check or similar means for payment to third parties or others, and is engaged in the business of making commercial loans. ${ }^{4}$ Grgurek defines banks as institutions that are collecting deposits,

1 See Dobbs; etc.: No Ordinary Disruption - The Four Global Forces Breaking All the Trends.

2 The benefits are the profits earned related to the implementation of new technology (or the cost-cutting related to the implementation), the increased utility and may even include such "non-economic" factors as the enjoyment. See Hall: Adoption of New Technology - Working Paper 9730. One can presume that enjoying such benefits may incentivize the users to "need" more services that have been transformed due to the implementation of the technologies.

3 See Garner: Black's Law Dictionary - Eighth Edition.

4 See Leko: Tradicionalno definiranje banaka i suvremene "full-service" banke. 
making loans, and providing financial services. ${ }^{5}$ From the definitions above, it is obvious that the banks are defined by the services they are providing.

The definitions indicate that banks are institutions that are providing depository and credit services; meaning that they are taking deposits from their customers, which are later repackaged and offered to the market as loans. The depository and credit services banks are providing are central services as the banks are making a profit on the margin and charging a fee for them. Banks are also providing money transfer services by enabling their customers to transfer funds from one account to another and to execute payments. Depository and credit services, together with the payment's services can be categorized as commercial banking services to commercial and/or retail customers. ${ }^{6}$ Commercial banks represent key financial intermediaries in the financial market. ${ }^{7}$

Another (traditional) feature that is characteristic for a commercial bank is that it operates net of branches. Branches make an essential part of a bank's operations as its "storefront" and customer-advisory functions. ${ }^{8}$ A wide net of branches, however, increases the fixed cost of doing business because a bank must cover the cost of rent(s), employees' salaries, security, etc. The trade-off is that, in the existing set-up, a wide net of branches enables commercial banks to provide their services to a larger number of clients. The wider the net of branches, the larger market share a bank could achieve and retain.

Progress and development of financial markets have led to the development of financial products and services that are becoming more complex, which in turn, makes them less accessible/attainable to clients. A number of services the banks are providing are fine-tuned for the needs of the big clients and completely out of reach for the small investors. The lack of basic product in the market may be moving the small investors towards alternative services.

Another factor constraining the adaption of the banking services and business model are the regulatory barriers. The speed of the banking sectors' adjustment to the changes in the market and to the needs of their customers must be observed in light of the strict regulation covering the financial sector. When

\footnotetext{
5 See Grgurek; Vidaković: Bankarsko poslovanje.

6 The Dictionary of Banking \& Financial Services defines commercial banks as banks that generally specialize (d) in demand deposits and commercial loans. Thus, this article is referring to crediting and depositing together with the money transfer as commercial bank services. See Rosenberg: Dictionary of Banking \& Financial Services - Second Edition.

7 See Madura: Financial Institutions and Markets.

8 According to McKinsey research, between $30 \%$ and $60 \%$ of customers choose branches for doing at least some of their banking in European nations. See Dallerup etc.: A bank branch for the digital age.
} 
transforming the existing services and offering new services to their customers, banks may have to confer with the regulator.

The services banks are providing, are not limited to the commercial banking services. Development of the financial sector has increased the volume of the services banks are providing to customers. In addition to commercial banking services, banks are providing investment banking services such as trading services, advisory services, underwriting, asset management, valuation services, etc. Investment banking is a non-legal but thematic subcategory of banking. An 'investment bank' is a financial institution whose fundamental job is to help finance the long-term capital needs of business and governments. ${ }^{9}$ What separates investment banks and commercial banks, besides the services provided to its customers, is the extent of risk their customers are exposed to. In some jurisdictions, investment banks will form a separate class of financial institutions due to regulatory requirements. The reason for this is to protect the customers from risks which are omnipresent in investment banking. At a point in time, in the US, it was prohibited to provide both commercial services and investment services. In the European market, prevailing banks will be providing both commercial and investment services.

\section{COMMERCIAL BANKING SERVICES IN THE LIGHT OF THE $2^{\mathrm{TH}}$ CENTURY TECHNOLOGY}

This chapter is examining the innovations in commercial banking that are directed to consumers' experience. The way commercial banks provide a service via "bricks and mortar" distribution models ${ }^{10}$ to their clients has not changed significantly compared to the Italian banks in the 15 th century. ${ }^{11}$ That being said, a range of automated and/or digital solutions have revolutionized how customers can have "control" over their access to funds. The introduction of automated teller machines (ATM), online banking and credit cards have all been advanced as part of increased financialization but also ability to increased consumer spending.

ATMs were firstly introduced in the 1970s. ${ }^{12}$ By the introduction of ATMs, banks have enabled its customers to have more independent access to their

\footnotetext{
9 See Fohlin: A Brief History of Investment Banking from Medieval Times to the Present.

10 "Brick and mortar" refers to a physical presence of banks/banks' branches. "Bricks and mortar" distribution model refers to the distribution model banks are operating in described in chapter 3 .

11 See Jacques, etc.: Reimagining the bank branch for the digital era.

12 See Scholnick, etc.: The Economics of Credit Cards, Debit Cards and ATMs: A Survey and Some New Evidence.
} 
bank accounts. It made customers less dependent on the working schedule of bank branches or their location. Similar to the banking branches network, the value of the bank's ATMs network increases with size. ${ }^{13}$

The innovation that enabled the customers to become even more sovereign in relation to banks was the introduction of transactional websites - online banking. Online banking was broadened in the late 2000s. ${ }^{14}$ Online banking entails transactional website which allows the customers, to be independent of bank branches' working schedule or their location. Moreover, it allows the customers from any point of the world that has Internet coverage to autonomously access their bank accounts and execute payments. Banks have incentivized their customers to use online banking by charging lower transaction fees for online banking transactions compared to the transaction fees for payments done by a bank teller in a bank branch.

Besides the ATMs and online banking, an important innovation was the introduction of non-cash payments by cards ${ }^{15}$. Cards are a replacement for cash money as they allow their customers to utilize their funds via cards and to use cards as a method of electronic payment ${ }^{16}$. The cards and online banking enable electronic payments and execution of financial transactions by online data exchange. ${ }^{17}$ Although ATMs, online banking and credit card do allow a certain degree of independence in executing payments, the services are inseparable of the banking system which makes the customers reliant on the commercial banks. It means that even though clients are independently executing transactions, banks are still stepping in the middle of the transactions; as will be explained in more details in chapter 5.3.

The trends in the commercial banking industry show that banks aim to implement digital infrastructure (online interfaces) in order to adapt their services

\footnotetext{
13 See Scholnick, etc.: The Economics of Credit Cards, Debit Cards and ATMs: A Survey and Some New Evidence.

14 In the year 2007, $77 \%$ of commercial banks offered online banking to their customers. See Frame; Mester.: Technological Change, Financial Innovation, and Diffusion in Banking.

15 Cards can be used for money transfer, debt, consumer benefits, etc. Cards may involve a large number of prices such as interest rates, teaser rates, grace periods, penalty fees, annual fees, etc and quantity constraints (credit limits, minimum payments, etc.). See Scholnick, B.; etc.: The Economics of Credit Cards, Debit Cards and ATMs: A Survey and Some New Evidence.

Cards refer together to credit cards (that allow the later payment), debit cards (that allow direct payment) or prepaid cards (that allow advance payment).

16 See Grgurek; Vidaković: Bankarsko poslovanje.

17 See Hrvatska Narodna Banka: $E$ - novac.
} 
and meet the preferences of global consumers. The adaptation is focusing on providing customized and on-demand services. ${ }^{18}$

\section{FINTECH - THE NEW GAME IN TOWN}

The penetration of innovative technologies has so far been less evident in the banking sector compared to other industries. Following the crisis, a range of new financial services providers - who are not banks - emerged across markets. The term "FinTech ${ }^{19}$ firms" refers to those services providers who create digital infrastructures and provide digital banking services. The FinTech firms are providing financial services that can be divided into four clusters (i) credit, deposit, and capital raising services, (ii) payments, clearing and settlement services, (iii) investment (management) services and (iv) other financial-related activities. ${ }^{20}$ Most often FinTech will have an online interface which will allow its clients' uncomplicated usage of the banking services. FinTech service providers are focused on offering their services to small investors.

The FinTech industry is growing rapidly. ${ }^{21}$ In the first half of 2018, $\$ 57.9$ billion was invested in ( 875 deals) in Fintech companies globally. Five years before, in the first half of 2015, $\$ 4.8$ billion was invested in (875 deals) in Fintech companies globally. ${ }^{22}$ That shows that in five years there was a tenfold increase in the investments in Fintech firms globally. Such growth is indicative that the FinTech firms have recognized the needs, the demands and the preferences of the consumers/clients. The FinTech firms have shifted their focus to the mobile technologies to meet the FinTech's consumer demand. ${ }^{23}$ The swift reply to the preferences of the consumers is feasible because FinTech firms are

18 See Jacques, etc.: Reimagining the bank branch for the digital era. and Dallerup etc.: $A$ bank branch for the digital age.

19 Oxford Living Dictionary defines FinTech as computer programs and other technology used to support or enable banking and financial services (an abbreviation of financial technology).

20 See European Banking Authority: Discussion Paper on the EBA's approach to financial technology (FinTech).

21 In the year 2015, it was estimated that there are 4,000 active FinTech startups in the market and that the value of more than ten of the active FinTech startups exceeds USD 1 billion. See The Economist: Why FinTech won't kill banks.

22 See Pollary: The Pulse of Fintech 2018: Biannual global analysis of the investments in Fintech.

23 The PwC's Global Consumer Insights Survey 2018 - New consumer behaviors, new business solutions reports that over the course of six years, the number of global consumers who shop via mobile phone has grown by $133 \%$. See PwC's Global Consumer Insights Survey 2018 - New consumer behaviors, new business solutions. 
constantly developing their services due to their flexibility. The flexibility is the consequence of the size and set-up FinTech is working in and due to the fact that they are working out of the reach of a regulator. The gap in the regulatory environment, together with the reduction of entry cost and the cost of providing services has removed the entry barriers which are characteristic for the banking sector.

The services that FinTech firms provide are often not territorially bound. Not being focused on a territory of one state permits the FinTech firms to create distribution models that can reach a global market provided that no technical or regulatory "geo-blocking" or other sales barriers exist. The FinTech is especially important for underdeveloped markets. In underdeveloped countries, the population can be underbanked and therefore averted from using any banking services. This paper will show how FinTech firms have found a suitable solution to provide banking services to underbanked individuals and its potential to provide services of the same quality to all people with Internet access, regardless of the development status of the country they live in.

Although FinTech firms have created new types of services which may have disrupted some components of the banking system, or at least caught its attention, for a number of these "new" business activities FinTech firms are still relying on the "traditional" banking infrastructure. The share of the market that FinTech has obtained cannot be compared with the market share the banks have. Even so, the banking sector has recognized FinTech as a competitive industry. ${ }^{24}$ The banking sector is presuming that the technology and the non-conventional service providers (FinTech) will be impacting it. The Economist's Report shows that the banking sector is expecting FinTech firms to be executing more transactions than traditional banks by $2020 .{ }^{25}$ Based on a recent Mayer Brown Report ${ }^{26}$, the collaboration of the financial institutions and FinTech is expected in the future either as banks taking over existing (FinTech) service providers or by forming a joint venture. Nevertheless, the banking sector will definitely be investing in digital solutions in the near future.

The following chapters discuss if the services FinTech firms provide are parallel/"partner-able" to the commercial banking services, it will also discuss how if FinTech firms can take the place of the commercial banks, and if developing technology is influencing money.

\footnotetext{
24 The Mayer Brown report shows that $85 \%$ of the respondents see independent FinTech as a moderate or great treat to commercial banking. See Mayer Brown: The ABC of Fintech - Acquisitions, Brexit and Collaboration.

25 See The Economist: Intelligence Unit Retail banking - In tech we trust.

26 See Mayer Brown: The ABC of Fintech - Acquisitions, Brexit and Collaboration.
} 


\subsection{CROWDFUNDING - A NEW METHOD OF CREDITING.}

Following the financial crisis, many individuals and business have been struggling with obtaining credit. FinTech recognized the discrepancies in the market and designed a new method of funding/crediting. This chapter will define bank credits, discuss the difficulties in obtaining credits, and display the crediting service FinTech is providing (crowdfunding) as an alternative to bank loans.

The Dictionary of Banking \& Financial Services defines a bank credit as a credit created by commercial banks through the media of loans and discounts granted with or without collateral. ${ }^{27}$ Crediting is defined as providing an amount of money from a financial institution as a creditor to a person on the other side as the debtor, with the promise that the debtor will return the borrowed amount together with the agreed interests. ${ }^{28}$ It is one of the central services banks are providing to its customers. ${ }^{29}$ When deciding on providing credit, a bank will be estimating the risk, the debtor's credit rating and other relevant criteria, on the side of which a bank would often seek adequate security for the case of default. The demanding prerequisites are deterring customers from obtaining credits.

The existing funding channels are not meeting the demand of the customers. In the European Union, as much as $13 \%$ of SMEs' applications for loans are rejected. ${ }^{30}$ The deficiency of adequate funding channels places barriers to pursuing promising ideas and prevents entrepreneurs in accomplishing their business plans which limit economic growth.

The rise of FinTech has introduced new methods of lending/crediting i.e. a new method of financing - crowdfunding. Crowdfunding allows direct transfer of the funds from the ones who have them to the ones who need them. Through crowdfunding, people who cannot meet the demanding prerequisites banks are setting, can obtain funding. ${ }^{31}$ In that way, FinTech has become an alternative to the traditional method of financing by obtaining credit from a bank or issuing securities. The example shows the potential FinTech has in distinguishing the challenges the market is dealing with and the right amount of imagination to create a new service.

\footnotetext{
27 See Rosenberg: Dictionary of Banking \& Financial Services - Second Edition.

28 See Leko; Jurković: rječnik bankarstva.

29 See Grgurek; Vidaković: Bankarsko poslovanje.

30 See European Commission: GREEN PAPER - Building a Capital Markets Union.

31 See Bruckner: Regulating Fintech Lending.
} 
Crowdfunding platforms are online platforms. Hence, they are (often) accessible from any part of the world. In many of the cases, the fund-seeker on a crowdfunding site can be any person with Internet access. Therefore, crowdfunding sites are offering crediting (and investing) opportunities to customers regardless of their geographical location. Investors from specific countries or fund seekers from specific countries may be limited through regulatory barriers. $^{32}$

Crowdfunding enables individuals and business entities to raise funds from the public but without the need for a traditional intermediary - i.e., bank. With financing through crowdfunding, a fund-seeker presents its project to the public through the online platform, and the funds are provided by a crowd as an investor. The investment decision depends on the interaction of a project and the crowd. The crowd will make an investment decision based on the presentation offered on the Internet platform. As compensation for the investment, the investor may receive interest, shares, bonds, non-financial compensation or another type of compensation. Depending on the way an investor will receive their compensation for the investment crowdfunding can be divided into ${ }^{33}$ : investment-based crowdfunding ${ }^{34}$, lending-based crowdfunding ${ }^{35}$, dona-

32 Crowdfunding platform Kickstarter allows users from any country to become a creditor of a project that seeks financing through that platform. The fund seekers may be only from selected jurisdictions: USA, UK, Canada, Australia, New Zealand, the Netherlands, Denmark, Ireland, Norway, Germany, Singapore, France, Spain, Italy, Mexico, Luxemburg, Belgium, Austria or Honk Kong. See Kickstarter: Creator questions.

In the EU the platforms that are active are registered in the EU, as well as in the USA, Canada, Australia, and China. See the European Commission: Crowdfunding in the EU Capital Markets Union - Commission Staff Working Document.

33 See European Commission: Crowdfunding in the EU Capital Markets Union-Commission Staff Working Document.

34 Companies issue equity or debt instruments to the crowd-investors through a platform. Therefore, the investors who will be investing in a project will receive security, share or bond. Depending on the instrument, the compensation will be either dividend or interest. The investment-based crowdfunding where companies issues shares (equity crowdfunding) is rare because of the regulation covering the issuance. See European Commission: Crowdfunding in the EU Capital Markets Union - Commission Staff Working Document.

35 In lending-based crowdfunding (also known as crowdlending, peer-to-peer or marketplace lending), companies or individuals seek to obtain funds from the public through platforms in the form of a loan agreement. The fund seeker will return the borrowed amount together with the interest rate. See European Commission: Crowdfunding in the EU Capital Markets Union - Commission Staff Working Document. 
tion-based crowdfunding ${ }^{36}$, rewards-based crowdfunding ${ }^{37}$ and invoice-trading crowdfunding ${ }^{38}$. The diverse compensation methods for the investors indicate that crowdfunding financing is not only focused on business, but it can also be deployed for charitable societies or private causes.

Besides obtaining credit, crowdfunding allows an investing opportunity to small investors who may not have access to capital market investments and/ or other products. Nevertheless, the investors investing in such opportunities must be aware that, although the profits may be higher than in a more conservative investment opportunity ${ }^{39}$, the risk is definitely higher. When providing loans to the market, banks will conduct due diligence in order to estimate the risks connected to the investment. The investors on a crowdfunding platform do not have the same possibility to assess the risks of their investment. The investors are provided with the information the fund seeker presents them with. As the sector remains fairly unregulated the risk is that neither all the relevant information is presented, nor is it clear who is liable for the statements made. Issuances of securities on a regulated market (IPO) ${ }^{40}$ are covered with high regulation. The regulation aims to reduce the risks by demanding the disclosure of relevant information ${ }^{41}$ and imposing liability ${ }^{42}$ on the issuer and persons responsible for the accuracy of the information disclosed. At this point, there

36 Individuals donate amounts to meet the larger funding aim of a specific charitable project while receiving no financial or material return. Charity organizations will often raise funds through donation-based crowdfunding. See European Commission: Crowdfunding in the EU Capital Markets Union - Commission Staff Working Document.

37 In reward-based crowdfunding, the individuals donate to a project expecting to receive a non-financial contribution, such as goods or services. See European Commission: Crowdfunding in the EU Capital Markets Union - Commission Staff Working Document.

38 Invoice trading crowdfunding is a form of asset-based financing whereby businesses sell unpaid invoices or receivables through an online platform. The invoices or receivables can be sold individually or in a bundle. See European Commission: Crowdfunding in the EU Capital Markets Union - Commission Staff Working Document.

39 The more conservative investment opportunities could be keeping money in a bank while earning steady interest rate or investing cash into real estate.

40 For the purposes of the comparison, a crediting and IPO are discussed as alternatives to financing with crowdfunding.

${ }^{41}$ See Commission Regulation No 809/2004 of 29 April 2004 implementing Directive 2003/71/EC of the European Parliament and of the Council as regards information contained in prospectuses as well as the format, incorporation by reference and publication of such prospectuses and dissemination of advertisements.

42 See Article 11 of the Regulation (EU) 2017/1129 of the European Parliament and of the Council of 14 June 2017 on the prospectus to be published when securities are offered to the public or admitted to trading on a regulated market and repealing Directive 2003/71/ECText with EEA relevance. 
is no regulation covering the crowdfunding sector that would ensure the level of investor protection. The high risks may be mitigated by covering the crowdfunding platforms with the strict regulation that covers financial institutions.

Crowdfunding is a financing method well accepted from customers around the world. Statista reports that the value of funds raised through crowdfunding globally between 2014 to 2016 reaches 2.1 billion dollars. ${ }^{43}$ The advance of crowdfunding shows how the FinTech has recognized and sealed a gap in the market. Moreover, Bruckner argues that Fintech lending allows especially to marginalized communities access to credit, and by indirectly encouraging innovation in the financial services sector which

\subsection{IS FINTECH HINTING TOWARDS A MORE EFFICIENT PAYMENT SYSTEM?}

In addition to crediting, service commercial banks are providing is money transfer and/or executing payments - payment services. This chapter will explore the money transfer services banks are providing their customers to. It will review the parallel services some FinTech firms are providing in that respect and examine if the services are benefiting the customers. The chapter will examine if the money transfer services FinTech firms have offered the users are more suitable for their needs. It will review the duration of transactions, fees charged for a transaction and access to banking infrastructure as factors impeding the efficiency of the payment system.

An international money transfer may take up to several days. The time needed for executing a transaction is another factor decreasing the efficiency of the existing money transfer system. The time period needed to execute a transaction increases the risks of the transaction ${ }^{44}$ and decreases the efficiency of the system.

\footnotetext{
43 Statista is a provider of market and consumer data. See Statista: Crowdfunding - Statistics \& Facts.

44 One of the reasons why the duration of a transaction effects its risks is the volatility of currencies. A value of a currency may change significantly in a short period, for example, the Turkish lira lost $12 \%$ of its value in one day in August 2018. See Jones: Currency volatility gauges ignite as Turkish lira turmoil spreads. If the value of the currency changes during the execution of the transaction the other party may receive an inaccurate value. Another example of the effect of the duration of a transaction on its risk is the intermediary going bankrupt, as it happened with Lehman Brothers. Such a scenario is rarely to play-out, but when it does the effects are immense. The funds transferred will most likely remain in the intermediary, and be retrieved only after the termination of the bankruptcy proceeding.
} 
When a bank is executing a payment, it will habitually charge its customer a fee. The fee charged varies. The fee will be higher for an international transaction, and lower for a domestic transaction, even more so for a transaction in the same bank. The fees banks are charging for money transfers are not proportional to micropayments. Micropayments are the payments of small amounts of money. Depending on the author, small amounts of money is defined differently. The Croatian Academic and Research Network defines the micropayments as payments of an amount not exceeding 1 cent. ${ }^{45}$ Gille defines micropayments as electronic payments that do not exceed 1 EUR. ${ }^{46}$ Nevertheless, the disproportional fees thus impede the attraction of micropayments. The disproportional fees may prevent entrepreneurs from charging their services and products which may further limit economic growth. Some FinTech firms have focused on providing an interface that enables quicker, more efficient and convenient micropayments. ${ }^{47}$

Another global issue that FinTech firms have been addressing is a financial exclusion. Financial exclusion is a term that describes the persons who are underbanked; persons who do not have access to traditional banking services, or banks, due to the underdeveloped status of a country or area they live in. The United Nations has set the reaching of financial inclusion as one of the seventeen Goals of sustainable development. ${ }^{48}$

The FinTech firms have started to mend the financial exclusion by creating alternative payment infrastructure that is offering banking services in the underdeveloped areas. An example of FinTech's action in battling the financial exclusion is m-pesa started by a mobile service provider - Vodafone in 2007. It enables a vast number of people, who do not have access to a bank account but do have a mobile phone, to transfer money through their mobile phone. ${ }^{49} \mathrm{~m}$-pesa is a suitable solution for countries such as Kenya, where only $10 \%$ of the population has access to traditional banking services, while more than $50 \%$ of the population has a mobile phone ${ }^{50}$. In April of 2016 m-pesa had more than 25 million active users in Kenya, Tanzania, South African Republic, Democratic Republic of Congo, India, Mozambique, Egypt, Lesotho, Ghana, Albania, and Romania. ${ }^{51}$

\footnotetext{
See CARNet: Elektronički novac.

46 See Gille: A transaction cost analysis of micropayments in mobile commerce.

47 FinTech company Flattr $A B$ enables journalists, artists, bloggers and other creators to get direct contributions from their supporters. See Flatter: More answers, less doubt.
} 
Mm-pesa is an operative example of how a technological solution can be deployed to increase the efficiency of the financial market. Similar to the crowdfunding, FinTech has recognized the opening in the market and created an adequate solution to seal it. Furthermore, m-pesa is highlighting how one technological solution is suitable for various jurisdictions. It operates in Romania, an EU member state, Albania a candidate EU-member state, as well as in African and Asian countries. This again shows how technological solutions are not geographically limited.

Implementation of technological solutions in banking infrastructure, such as online banking and credit cards, has modernized the payment system. FinTech has taken the modernization a step further. The FinTech firms provide a faster, more efficient, independent and less expensive money transfer $(\text { PayTech })^{52}$ by which they have entered into the market as a promising participant.

\subsection{BANKS AND MONEY - CAN THE PILLARS OF THE FINANCIAL SYSTEM BE DIGITALIZED?}

This chapter will firstly explore if the set-up traditional banks are operating in can be altered by the implementation of the digital infrastructure. It will examine the setup of Atom plc as an example of a FinTech Firm providing banking services (Internet-only bank). In its second part this chapter will discuss the possibilities cryptocurrencies may be hinting toward, and the effect the transfer of (central-bank) money to channels based on blockchain technology may have on the banking sector.

\section{"Banking is essential, banks are not"}

Has the technology reached the state of development at which the famous Bill Gates's forecast from $1994^{53}$ could be materialized? Bill Gate's forecast that in the future one will need the banking system but not necessarily the banks has been radical in the point in time it was made. In the existing market, the FinTech firms have demonstrated that the banking services can be independent of the banking sector and provided to the customers outside the banking system. Moreover, the moment for the shift to the online banking services might be right, as a McKinsey \& Company study shows that a large portion of respondents is open to digital banking channel, and that as much as $56 \%$ of customers would be willing to purchase banking products digitally. ${ }^{54}$

$52 \quad$ See Haycock; Richmond, S.: Bye bye banks?

53 See Groenfeldt: Mobile banking trends will leadto change in banking 2016.

54 See Jacques, etc.: Reimagining the bank branch for the digital era. 
The liberalization of the regulatory environment surrounding the banking system has facilitated the launch of the first so-called Internet-only banks in the UK. An internet-only bank is a bank that is providing banking services exclusively through an online interface. They tend to pay higher interest rates compared to traditional banks. ${ }^{55}$ An operating example of an Internet-only bank is the Atom bank plc launched in 2016. ${ }^{56}$ Atom provides banking services exclusively through a mobile app. ${ }^{57}$ At this point, it is not possible to open an account without their app. Atom has no branches where customers could com, or employees who'd serve the customers. But then again it offers its clients 24/7 helpdesk support. ${ }^{58}$

Atom is an example of how the set-up of an Internet bank (digital infrastructure) eliminates the need for a wide net of branches. Atom is offering its services (exclusively) through a digital interface, hence it can be providing its services anywhere within the authorized jurisdiction. Therefore, it does not need a wide net of branches to gain market share. At the existing regulatory set-up, Atom is offering its services to UK citizens only. ${ }^{59}$

In contrast, commercial banks employ a greater number of employees in a number of branches. Yet employees and the branches cause high fixed and variable expenses. ${ }^{60}$ Internet-only banks have eliminated such expenses, as they have neither branches nor employees. The absence of banking branches and employees increases the flexibility of an Internet-only bank and increases its efficiency. As previously mentioned, the trends in the market are showing that the banking industry is moving towards providing more of its services online. The size of the banks and the strict regulatory environment may be preventing the existing banks to change their business model completely and provide the services to their customers only through an online interface. Besides, not all the customers may be ready for such a drastic transition.

The great asset that banks have is their reputation and the trust the market confides in them. The reputation and trust are one of the reasons the customers keep their money in the banks. Without gaining the reputation and the trust

\footnotetext{
$55 \quad$ See McCormick: Best Online Only Banks of 2018.

56 Atom bank plc isauthorizedd by the Prudential Regulation Authority (PRA) and regulated by the Financial Conduct Authority (FCA) and the PRA. It is registered under the Financial Services Register number 661960. See Atom: The future of banking, available today.

57 See Atom: FAQ.

58 See Atom: FAQ.

59 See Atom: FAQ.

60 See Rončević: Nove usluge bankarskoga sektora: razvitak samoposlužnoga bankarstva u Hrvatskoj.
} 
of the market, Internet-only banks or other FinTech firms cannot represent a proper alternative to the established banking system. Time will show how likely it is for the customers to confide their finance to a not established service provider. Nevertheless, Internet-only banks and FinTech are leading the path which the industry is following.

\section{Bitcoin is here to stay! ${ }^{61}$}

Banking and banking services are inevitable when it comes to transactions with money. Money, together with the banks which facilitate money transfer, is what is making the global trade of goods possible. ${ }^{62}$ Similar as the banks the , money will more often than not be defined by its functions - medium of exchange, temporary abode of purchasing power, store of value, unit of account (standard of value) and standard of deferred payment ${ }^{63}$ and its characteristics - transferability, durability, scalability, standardization, and identification and by its issuer; the central bank. The introduction of cards and electronic payments was a step toward the transformation of money and eliminating it in its physical form - cash.

The benefits of going cashless are plenty. It benefits consumers as well as providers. Cashless transactions are more transparent. They allow less demanding control of the payments made. Consequently, it is less demanding to collect taxes, enforce anti-money laundering provisions, fight black market, s etc. Moreover, the cost of printing the money, its transport and safe-keeping would be reduced. Cashless payments by cards are providing the customers with a certain degree of independency from the banking system.

The independency is illusory since the banks still step in as intermediaries in the transactions as the, online transactions are most often performed with the involvement of a bank - a trusted intermediary ${ }^{64}$ who will guarantee not only the identity of the parties involved but the success of the transaction ${ }^{65}$ conducted on. One of the reasons why the online transactions require verification from a trusted third party is that in an online transaction parties cannot, reliably, establish one another's identity. Consequently, one party does not know if the

\footnotetext{
${ }_{61}$ This phrase does not reflect the author's position on a single cryptocurrency - the Bitcoin, nor on the lot. The phrase wishes not to single out Bitcoin. Bitcoin here is used as a wider term for all cryptocurrencies. The phrase aims to raise the question: Can the efficiencies cryptocurrencies displayed in the market be ignored?

62 See Grgurek; Vidaković: Bankarsko poslovanje.

63 See Auerbach: Money, Banking, and Financial Markets.

64 The trusted third party will usually be a bank, or a credit card company.

65 See Barclaycard: How do online payments actually wor
} 
other one is good for it, i.e. if the other party, in reality, has the money or assets, and is the rightful owner of the object of a transaction. As a result, when transacting online, a trusted intermediary steps in the middle of a transaction and provides the trust of an online transaction.

The recent developments in technology have reached the point where cashless money transfer may become independent of the banking system. The controversial cryptocurrencies ${ }^{66}$, popularized by bitcoin, are introduced as the new medium of online payment. ${ }^{67}$ The blockchain technology underlying the cryptocurrencies allows the direct transfer of an asset (money) from one party to another. Therefore, it eliminates the need for a transaction to be verified by a trusted third party (a bank, or a credit card company).

Cryptocurrencies allow (almost) instant settlement, direct online payments without traditional intermediaries (banks), and secure depositing of "money" in private wallets. Cryptocurrencies, due to their technical characteristics (direct transfer and almost instant settlement), are a more adequate medium for executing online payments. The instant settlement and the direct payments reduce intermediary cost and increase the speed of a transaction. Even so, at the point of the regulatory framework, cryptocurrencies do not fall under the definition of money as they are not issued by a central bank, as they are not generally accepted as a form of payment, due to their volatility, and as they leave the customers unprotected.

As mentioned, at this point in time only a few online sites will accept cryptocurrencies as a method of payment ${ }^{68}$. US retailer, Overstock.com, was one of the first online retailers that accepted cryptocurrencies as a method of pay-

${ }^{66}$ See European Central Bank: What is bitcoin?

European Central Bank defines cryptocurrencies as digital representations of value which, despite not being issued by a central bank ... are voluntarily accepted, by natural or legal persons, as a means of exchange, and which are stored, transferred and traded electronically, without a tangible, real-world representation. See Athanassiou: Legal Working Paper Series - Impact of digital innovation on the processing of electronic payments and contracting: an overview oa flegal risk.

${ }^{67}$ Blockchain technology is the technology underlying the cryptocurrencies. The specific features of blockchain technology that makes it adequate for integration ithe $\mathrm{n}$ financial sector ae: traceability of transaction, safety and 10 minutes update, verification and settlement of transactions. It is expected the blockchain could be used for various purposes ithe $\mathrm{n}$ financial sector such as depositing and lending in syndicated loans and trade finance, in ensuring monitoring and execution of CoCo bonds. See World Economic Forum: The future of financial infrastructure - An ambitious look at how blockchain can reshapthe e financial sector.

68 One can use Bitcoin to deposit funds into their Microsoft account, buy gadgets from Newegg Overstock.com or even order pizza form PizzaForCoins or BitPizza. See Moreau: 15 Major Retailers and Services That Accept Bitcoin. 
ment. ${ }^{69}$ Bearing in mind the rapid growth of online shopping and online services, it is to presume, the market will move towards cryptocurrencies as a more efficient method of payment. The Chinese online store Alibaba perfectly depicts the growth of online shopping. In the year 2015 for Chinese national singles day (11 November) Alibaba has had record sales of USD 14 billion $^{70}$ For the same holiday in the year 2016 Alibaba achieved record sales of USD 23.39 billion. $^{71}$

Currently, it is not possible to assert in which direction the technology revolving around cryptocurrency will be evolving. Considering the trends in the market, especially the presented growth in online shopping, it is not surprising that the market is presuming the central bank money could in the future be registered on the blockchain technology. ${ }^{72}$ If that will be the case, the cashless payment system may become (entirely) independent of commercial banking, as the trusted intermediary (bank) would no longer be required to guarantee transactions. It may become redundant for the banks to transfer money if the technology permits secure, direct, instant, cashless payments and the money is deposited in private wallets. If the customers could be executing cashless payments securely without a bank, need for banks to be providing payment services would also be eliminated or reduced to a minimum level.

Furthermore, blockchain technology allows secure depositing of cryptocurrencies in private wallets. Therefore, in the future, the customers may not be incentivized to deposit money in a bank because holding the monies in their wallets would, due to their technical characteristics, provide a sound level of security. The security, the wallets are providing could render checking account obsolete. ${ }^{73}$ In that case, banks would have to incentivize their clients to keep the funds deposited.

Such a scenario would, without a doubt, affect the services (depositing and money transfer) the banks are providing in the existing set-up.

${ }_{69}$ Overstock.com accepted cryptocurrencies as a method of payment as of January of 2014. See Moreau: 15 Major Retailers and Services That Accept Bitcoin. and Overstock.com: Help Center.

70 See Dobbs: No Ordinary Disruption - The Four Global Forces Breaking All the Trends.

71 See ABC news: Singles' Day: Alibaba posts record sales as Chinese e-shoppers spend billions.

72 See European Securities and Markets Authority: Report - The Distributed Ledger Technology Applied to Securities Markets.

73 The uniqueness of the blockchain technology lies in enabling its users to transact online without a trusted intermediary. 
Considering the occurrences in the market, mentioned in this chapter, one may draw a conclusion that implementation of digital technology (in the existing banking infrastructure) or further development of FinTech would alter both the services the banks are providing (taking deposits and money transfer) and the set-up they operate in due to the shift to digital services. As discussed above, it is safe to assume the set-up banks operate in will change. It is safe to presume the banks will shift ta o more digital environment in relations to the customers. Moving to the more digital environment could result in decreasing the number of (if not eliminating) branches a bank has and employees a bank employs. The set-up banks may be operating in the future may be similar to the internet-only banks' set-up. At this point, it is challenging to forecast which bank services might survive due to the development and adoption of the new digital technologies.

\section{REGULATORY CHALLENGES IN FINANCIAL SERVICES THROUGH INNOVATIVE TECHNOLOGY}

In chapter 5, working out of the reach of a regulator was mentioned as one of the factors that supported the rise of FinTech firms. The European Banking Authority (EBA) has surveyed FinTech firms in the EU, to establish the proportion of the firms working under the (EU) regulatory framework. In EBA Discussion paper on the EBA's approach to financial technology (FinTech), it reports on the survey of 1500 FinTech firms established in the EU. The results show that $31 \%$ of the FinTech Firms are not subject to a regulatory regime under EU or national law and $17 \%$ are subject to a national registration/authorization regime. ${ }^{74}$ Considering the proportion, one must take into account the fact that the EBA has surveyed the FinTech firms it was informed about by the national competent authorities. The number of active FinTech firms in the EU is likely to be significantly higher, as well as the portion of the FinTech firms that are not subject to a regulatory regime.

\section{The particular requirements when imposing regulation on FinTech.}

When discussing the regulation of FinTech, one must have in mind the different starting points financial and technology sector have. The financial sector due to the great importance for society and the economy is submitted to strict and clear regulation and supervision. Financial regulation seeks to create a stable market and protect the public against losses by setting financial super-

74 See European Banking Authority: Discussion Paper on the EBA's approach to financial technology (FinTech). 
vision, authorization requirements for financial service providers, the rules on the conduct of business, establishing disclosure rules, placing strict liability for market frauds and establishing compensation funds. ${ }^{75}$ In short, financial regulation is set in place to reduce, if not eliminate systemic risk. ${ }^{76}$

On the other hand, technology-driven sector favors self-regulation. Less regulation leaves technology-driven businesses in a flexible environment which allow them to develop constantly and reach their full potential. Even though the technology used in the financial sector should be submitted to the same level of regulation, regulators should recognize that difference between the two sectors.

Another thing to keep in mind is that the timing of imposing of regulation on innovative technologies may affect both inclusion of the technology and its further development. Overregulating too early may slow down the $\mathrm{n}$ developing process, while doing so too late may create legal uncertainty and leave investors unprotected. ${ }^{77}$ Whys and wherefores of regulating at a later point in time include the idea that it may be a waste of efforts as the availability of technology may not mean it will be adopted in the market, and if the case may be regulators who were working on finding adequate solutions would be diverting their resources besides the argument that the technology may not yet have been fully developed. ${ }^{78}$

Moreover, recent advancements display that technological innovation emerges before regulators are prepared. ${ }^{79}$ Often, the existing rules are not applicable, and regulators and the legal framework are not ready for developing and enforcing rules as rapidly as novel products and services emerge. Such an environment leaves room for manipulation and consumer threats.

\section{The risks have arisen in the market.}

The importance of the financial sector for the society and the economics is pronounced. Nevertheless, when discussing regulation that ensures a stable

\footnotetext{
75 See Wood: Regulation of International Finance.

76 See Magnuson: Regulating Fintech. Magnuson defines systemic risk as the probability that economic shocks in one part of a financial system can lead to shocks in other parts of that system. Under Magnuson, four factors are main contributors to the systemic risk: (i) the size of a market, (ii) the vulnerability of individual actors to shocks, (iii) the shock absorbers set to limit the dispersion and (iv) the level of asymmetric information in the market.

77 See Ehrbeck: Financial Inclusion/ What's Next for Regulators?.

78 More elaborate argumentation on whyhe $\mathrm{t}$ technological solution may be regulated later can be found in Arner: The evolution of FinTech: A New Post-Crisis Paradigm?.

79 See Ehrbeck: Financial Inclusion/ What's Next for Regulators?.
} 
market, and mitigation of systemic risk, regulation of the FinTech sector cannot be left out. As FinTech firms are providing financial services, they are associated with systemic risk. ${ }^{80}$ Hence, the regulation must cover risks arising from the operations of FinTech.

When discussing regulation that is covering the FinTech sector one must have in mind is consumer protection. FinTech firms are stepping in the middle of (financial) transactions as new intermediaries. In crowdfunding, an online platform is the middle-man between the investor and the fund-seeker. Similar, when acquiring cryptocurrencies, customers are approaching trading platforms, or a sort of currency exchange platforms. ${ }^{81}$ At the existing state of the regulatory environment, these intermediaries (online platforms) are working out of reach of the regulators. The platforms do not fall under the regulation as the financial institutions do. Consequently, they do not provide the same level of security and scrutiny the banking sector provides. Considering the popularization and the rapid growth of the market, investors/customers could be vastly unaware of the risks such as intermediaries (and transactions) are associated with.

If the sector remains unregulated, the investors will remain unprotected, which will leave room for flaws in providing the services and unnecessary risks. That is why the regulators must design adequate regulation which would allow the further development of the FinTech industry and other digital solution in the banking sector while providing a reasonable degree of investor protection.

\section{The collaboration of the regulators and FinTech firms.}

Some regulators have recognized the special environment the Fintech firms require. For example, in 2015, the Financial Conduct Authority (the FCA) has introduced Project Innovate ${ }^{82}$. Through Project Innovate, the FCA works together with innovative technology-based projects supporting them and helping them to understand the regulatory framework and how it applies to them. Through Project Innovate, the FCA assists the technology-based projects in

\footnotetext{
80 For more information on why and how are FinTech firms associated with systemic risk see Magnuson: Regulating Fintech.

81 See Bitcoin.com: Standard Exchanges -Choose Where You'd Like to Buy \& Sell Bitcoin.

82 The Project Innovate (i) supports innovative financial products and services to the market (ii) provides regulatory feedback to firms developing models that seek to deliver lower cost advice to consumers and finally (iii) creates a 'safe space' in which businesses can test innovative products, services, business models and delivery mechanisms in a live environment without immediately incurring all the normal regulatory consequences of engaging in the activity in question. See Financial Conduct Authority: FCA Innovate.
} 
preparing and applying for authorization. ${ }^{83}$ After obtaining authorization, a technology-based projects is assigned a dedicated contact for a limited time period. ${ }^{84}$ In that way, the FCA ensures to be involved in the innovative technology-based projects and works with FinTech firms in finding solutions which are adequate within the existing regulatory framework. Such collaboration and conjoint development of regulators and FinTech firms may be an appropriate way for understanding the services FinTech firms are offering, risks involved, and ultimately finding adequate regulation for FinTech. Moreover, in such an approach, a regulator is more prepared to understand the developments in the market and the services provided. That may allow it to react promptly to developments in the market and decrease the regulatory gap.

When finding adequate regulation for FinTech firms legislators have to take into account that technological solutions are not geographically limited M-pesa demonstrates how one technological solution can be used in various countries. Even though, the technology does not recognize (national) borders, the regulation surely does. Confirming to different regulatory regimes, and dealing with different administrative systems may burden FinTech firms and cause unnecessary cost. FinTech firms will be setting-up their headquarters in a most favorable jurisdiction. ${ }^{85}$ That might incentivize regulators to create of a FinTech-friendly regulatory frame to incentivize FinTech firms to setting-up their headquarters in a specific jurisdiction.

\section{CONCLUSION}

This paper aimed to assess in digital technologies have the power to disrupt commercial banks' set-up and the services they are providing. As the paper has shown, the digital technologies have enabled the arrival of the new players in town - the FinTech firms which are providing services parallel to core banking services (lending and money transfer) to the consumers. At the time of writing FinTech's share of disruption is perhaps louder in perception than actual market share. Where the market share is being gained, it falls within two types. The first is where FinTech is leading the changing system independent of banks (this is particularly true in the payments sector and connected infrastructure) and the second is where FinTech is partnering to provide the technology to traditional financial market participants active in the commercial banking sector.

83 See Financial Conduct Authority: FCA Innovate.

84 See Financial Conduct Authority: FCA Innovate.

85 See Magnuson: Regulating Fintech. 
The FinTech sector has created innovative solutions - the services it is providing are offering new possibilities to the customers. Besides that, FinTech has shown its potential to close the existing gaps in the financial market. It is providing underbanked individuals efficient access to basic banking services where banks weren't able to (or incentivized to) do so. Additionally, they have designed the new method of crediting - crowdfunding. Crowdfunding allows individuals, who may not be creditworthy by banks' standards, to obtain credit. On the other side, it allows small investors an investment opportunity. This shows that FinTech firms have successfully recognized the needs of the market and fulfill them effectively.

An advantage of the FinTech firms is that they can (in most of the cases) deploy its technological solution, i.e. banking services regardless of the geographical location of the customer. Customers residing in specific countries may be prevented in using some of the services due to the regulatory environment. However, with the creation of an adequate regulatory environment, those hurdles could be mended.

The regulatory gap is one of the factors that permitted the fast development of the FinTech sector in the first place. Nevertheless, it is a challenge FinTech firms are faced with. Although imposing regulation on FinTech is immanent due to its close relation to the financial sector, choosing the right timing for setting the regulation may be one of the greatest challenges for the regulators. When designing the new regulation, the regulators will have to keep in mind the differences between the regulation applicable on the financial sector, and the regulation that favors the technology-driven sector.

As the FinTech firms are offering new possibilities to customers that the customers are accepting, the banking sector is moved by digital technology. The indications in the market show banks may be shifting their operations to an online interface and change their operating model, one can expect that the setup banks are operating in may be also moved by digital technology. Moreover, in some jurisdiction, the regulator has permitted the authorization of online banks. Such an atmosphere may lead to the abolition of the commercial banks in their existing set-up. It hints the banks could forsake the branches and be providing their services solely online. Such a shift would alter the structure of commercial banking and with it the services. Likewise, the transformation of money transfers to channels based on blockchain technology which is underlying cryptocurrencies could additionally affect the business model of the banks in the future.

It is irrefutable that the implementation of innovative technologies into banking services is disrupting the commercial banking sector and its services. The extent of the disruption cannot be foreseen. Nevertheless, it is unlikely that 
FinTech firms would take over the role of commercial banks. However, FinTech firms have alerted the banking sector and for some, it has pushed banks into creating a consumer-friendlier environment. That should be applauded in its own right.

\section{LITERATURE}

1. Arner, D.; Barberis, J.N.; Buckley R.P.: The evolution of FinTech: A New Post-Crisis Paradigm?https://papers.ssrn.com/sol3/Delivery.cfm/SSRN_ID2834841_ code722134.pdf?abstractid=2676553\&mirid=1, , accessed on 16/06/2017.

2. Auerbach, R. D.: Money, Banking, and Financial Markets, New York/ London, Maxwell Macmillan International Editions, 1989.

3. Athanassiou, P.: Legal Working Paper Series - Impact of digital innovation on the processing of electronic payments and contracting: an overview of legal risk, https://www.ecb.europa.eu/pub/pdf/scplps/ecb.lwp16.en.pdf?344b9327fec917bd7a8fd70864a94f6e, accessed on 01/10/2018.

4. Bruckner, M. A. Regulating Fintech Lending. Banking \& Financial Services Policy Report Volume 37, 1-7.

5. Hrvatska akademska i istraživačka mreža: Elektronički novac - CARNet, http:// www.cert.hr/sites/default/files/NCERT-PUBDOC-2010-09-311.pdf, accessed on $16 / 05 / 2017$.

6. Dallerup, K.; Jayantilal S.; Konov, G., Legradi, A; Stockmeier H.: A bank branch for the digital age, https://www.mckinsey.com/industries/financial-services/ourinsights/a-bank-branch-for-the-digital-age, accessed on 01/10/2018.

7. Dobbs, R.; Manyika, J.; Wertzel, T.: No Ordinary Disruption - The Four Global Forces Breaking All the Trends, New York, Public Affairs, 2016.

8. Ehrbeck, T.: Financial Inclusion/ What's Next for Regulators?, The Economist, https://perspectives.eiu.com/financial-services/financial-inclusion-whats-nextregulators, accessed on 16/06/2017.

9. The Economist: Why fintech won't kill banks, http://www.economist.com/blogs/ economist-explains/2015/06/economist-explains-12, accessed on 16/06/2017.

10. The Economist: TEconomistmis Intelligence Unit - Retail banking - In tech we trushttps://www.eiuperspectives.economist.com/sites/default/files/Retail\%20 Banking.pdf,f , accessed on 16/06/2017.

11. European Banking Authority: Discussion Paper on the EBA's approach to financial technology (FinTech). EBA. https://www.eba.europa.eu/documents/10180/1919160/EBA+Discussion+Paper+on+Fintech+\%28EBA-DP-201702\%29.pdf, accessed on 01/10/2018. 
12. European Commission: Crowdfunding in the EU Capital Markets Union - Commission Staff Working DocumenBrusselsles, European Commission. https:// ec.europa.eu/info/system/files/crowdfunding-report-03052016_en.pdf, accessed on $01 / 10 / 2018$.

13. European Securities and Markets Authority: Report - The Distributed Ledger Technology Applied to Securities Markets, Paris, ESMhttps://www.esma.europa. eu/system/files_force/library/dlt_report_-_esma50-1121423017-285.pdf,f , accessed on $01 / 10 / 2018$.

14. Fohlin, C.: A Brief History of Investment Banking from Medieval Times to the Present, Oxford Handbook of Banking and Financial History. https://ssrn.com/ abstract $=2524636$, accessed on 01/10/2018.

15. Frame, W. S.; Mester, L. J.: Technological Change, Financial Innovation, and Diffusion in Banking, Berger, P.; Molyneux, J. O.; Wilson; The Oxford Handbook of Banking (p. 486-507), Oxford, Oxford University Press, https://papers.ssrn. com/sol3/papers.cfm?abstract_id=2380060, accessed on 01/10/2018.

16. Hall, B. H., \& Khan, B. (n.d.). Adoption of New Technology - Working Paper 9730. Retrieved frhttps://www.nber.org/papers/w9730.pdf,f , accessed on 19/01/2019.

17. Garner, B. A.: Black's Law Dictionary - Eighth Edition, USA, Thomson West.

18. Gregurek, M.; Vidaković, N.: Bankarsko poslovanje, Zagreb, RRiF, 2011.

19. Gille, D.: A transaction cost analysis of micropayments in mobile commerce. Journal of Information and Organizational Sciences, (p. 25-31https://hrcak.srce. $\mathrm{hr} / 78219,9$, accessed on $01 / 10 / 2018$.

20. Haycock, J.; Richmond, S.: Bye bye banks?, London, Adaptive Lab, 2015.

21. Hrvatksa Narodna Banka: $E$ - novac, https://www.hnb.hr/o-nama/zastita-potrosaca/bezgotovinska-placanja/e-novac, accessed on 01/10/2018.

22. Jacques, F.; Nunez Maxwell, M.; Patiath, P.; Stephens, D.: Reimagining the bank branch for the digital era, https://www.mckinsey.com/industries/financial-services/our-insights/reimagining-the-bank-branch-for-the-digital-era, accessed on 01/10/2018.

23. Leko, V.; Jurković, P.: Rječnik bankarstva, Zagreb, MASMEDIA, 1998.

24. Leko, V.: Tradicionalno definiranje banaka i suvremene "full-service" banke, Novac, bankarstvo i financijska tržišta, Zagreb, Adverta, 2005.

25. Madura, J.: Financial Institutions and Markets, International Edition, Joe Sabatino, 2010.

26. Magnuson, W. Regulating Fintech. Vanderbilt Law Review, 1168-1226.

27. Mayer Brown: The ABC of Fintech - Acquisitions, Brexit and Collaboration, https://www.mayerbrown.com/files/uploads/PRSpecial/The_ABC_of_Fintech_ survey_November_2016.PDF, accessed on 05/04/2017. 
28. Oxford Living Dictionary: FinTech, https://en.oxforddictionaries.com/definition/ fintech, accessed on 01/10/2018.

29. Prabhu, J.; Radjou, N.: Do We Really Need Banks?, Harvard Business Review, https://hbr.org/2010/06/do-we-really-need-banks, accessed on 17/05/2017.

30. PwC: PwC's Global Consumer Insights Survey 2018 - New consumer behaviours, new business solutions, https://www.pwc.com/gx/en/industries/consumer-markets/ consumer-insights-survey/new-business-models.html, accessed on 01/10/2018.

31. Rončević, A.: Nove usluge bankarskoga sektora: razvitak samoposlužnoga bankarstva u Hrvatskoj, http://hrcak.srce.hr/8518, accessed on 05/04/2017.

32. Rosenberg, J. M.: Dictionary of Banking \& Financial Services - Second Edition, New York, John Wiley \& Sons Inc, 1985.

33. Scholnick, B.; Massoud, N.; Saunders, A.; Carbo-Valverde, S.; Rodriguez-Fernandez, F.: The Economics of Credit Cards, Debit Cards ATMsAtms: A Survey and Some New Evidence Journal of Banking \& Finance, Vol. 32, No. 8, pp. 14681483, August 2008; University of Alberta School of Business Research Paper No. 2013-1147. https://ssrn.com/abstract=899452, accessed on 01/10/2018.

34. United Nations: http://www.un.org/sustainabledevelopment/sustainable-development-goals/, accessed on 17/05/2017.

35. UN Capital Development Fund: Financial Inclusion and the SDGs, http://www. uncdf.org/financial-inclusion-and-the-sdgs, accessed on 01/10/2018.

36. Wood: Regulation of International Finance, London Sweet \& Maxwell, 2007.

\section{PREPARATORY DOCUMENTS}

37. ABC news: Singles' Day: Alibaba posts record sales as Chinese e-shoppers spend billiohttp://www.abc.net.au/news/2016-11-12/alibaba-posts-record-singles-day-sales/8019900,00, accessed on 17/05/2017.

38. Atom: The future of banking, https://www.atombank.co.uk, accessed on 01/10/2018.

39. Atom: $F A Q$, https://www.atombank.co.uk/faq, accessed on 01/10/20

40. Barclaycardcard. How do online payments actually work? Retrieved fhttps:// www.barclaycard.co.uk/business/accepting-payments/learn-about-taking-payments/how-do-online-payments-actually-work,rk , accessed on 19/01/2019.

41. Bitcoin.com: Standard Exchanges -Choose Where You'd Like to Buy \& Sell Bitcohttps://www.bitcoin.com/buy-bitcoin,in , accessed on 01/10/2018.

42. Commission Regulation No 809/2004 of 29 April 2004 implementing Directive 2003/71/EC of the European Parliament and of the Council as regards information contained in prospectuses as well as the format, incorporation by reference and publication of such prospectuses and dissemination of advertisements. 
43. Daily Nation: M-Pesa reports 27 pc jump in global users to 25 millihttp://www. nation.co.ke/business/M-Pesa-reports-27-pc-jump-in-global-users-to-25-million/996-3178018-5ykpjpz/index.html,ml , accessed on 17/05/2017.

44. European Central Bank: What is bitcoin?, https://www.ecb.europa.eu/explainers/ tell-me/html/what-is-bitcoin.en.html, accessed on 01/10/2018.

45. Financial Conduct Authority. FCA Innovate. Retrieved fhttps://www.fca.org.uk/ firms/project-innovate-innovation-hub,uaccessedesed on 19/01/2019.

46. Flatter: More answers, less doubt. https://flattr.com/faq, accessed on 01/10/2018.

47. Groenfeldt, T.: Mobile banking trends will lead change in banking 2016. https:// insights.samsung.com/2016/04/15/mobile-banking-trends-will-lead-change-inbanking-in-2016/, accessed on 01/10/2018.

48. Jones, M. Currency volatility gauges ignite as Turkish lira turmoil spreads. Retrieved fhttps://www.reuters.com/article/uk-markets-lira-volatility/currency-volatility-gauges-ignite-as-turkish-lira-turmoil-spreads-idUSKBN1KV1IM,Iaccessedesed on 19/01/2019.

49. Kickstarter: Creator questionhttps://www.kickstarter.com/help/faq/creator+questions,ns , accessed on 05/04/2017.

50. McCormick, E.: Best Online Only Banks of 2018, accessed on 01/10/2018. https://www.toptenreviews.com/money/services/best-online-only-banks/, accessed on $01 / 10 / 2018$.

51. Moreau, E. 15 Major Retailers and Services That Accept Bitcoin. Retrieved fhttps://www.lifewire.com/big-sites-that-accept-bitcoin-payments-3485965,65 , accessed on 19/01/2019.

52. Overstock.com. (2019, 01 19). Help Center. Retrieved from https://help.overstock. com/help/s/article/Bitcoin, accessed on 19/01/2019.

53. Pollary, I., \& Ruddenklau, A. (2019, 01 25). The Pulse of Fintech 2018: Biannual global analysis of the investments in Fintech. Retrieved fhttps://assets.kpmg/ content/dam/kpmg/xx/pdf/2018/07/h1-2018-pulse-of-fintech.pdf,daccessedesed on $19 / 01 / 2019$.

54. Regulation (EU) 2017/1129 of the European Parliament and of the Council of 14 June 2017 on the prospectus to be published when securities are offered to the public or admitted to trading on a regulated market, and repealing Directive 2003/71/ECText with EEA relevance.

55. Statista: Crowdfunding - Statistics \& Facts. Retrieved fhttps://www.statista.com/ topics/1283/crowdfunding/,g/, accessed on 01/10/2018.

56. World Economic Forum. The future of financial infrastructure - An ambitious look at how blockchain can reshape financial sector, Part of the Future of Financial sector Series, Retrieved from http://www3.weforum.org/docs/WEF_The_future_of_financial_infrastructure.pdf accessed on 01/10/2018. 